UDK 619:616-089.23

\title{
HISTOLOGICAL EVALUATION OF BONE RESPONSE TO BIOACTIVE CERAMICS AS GRAFT
} MATERIAL IN RATS

KRŠLJAK ELENA, DANILOVIĆ VESNA and TEODOROVIĆ NEVENKA

Faculty of Stomatology, Belgrade

(Received 21. March 2005)

This experimental study was carried out on 35 Albino Wister rats. Artificially created bone defects were grafted with bioactive ceramic materials or control material. Histological analysis was preformed 8 weeks and 6 months after the implantation. The results revealed that bone regeneration occurred in defects treated with bioactive ceramic materials, while in the defects treated with the control material signs of tissue rejection were present. As stated before, it could be concluded that bioactive ceramics can be recommended as bone substitutes in orthopaedic surgery and dentistry.

Key words: hydroxylapatite (Hap), Hap-M type 2, bone regeneration, histology

\section{INTRODUCTION}

A variety of artificial materials have been used during the past four decades to fill in bone defects. Ideally, bone grafts should be biocompatible, show minimal fibrotic reaction, undergo remodelling and support new bone formation. From the mechanical point of view graft materials should have similar strength and elasticity to that of bone being replaced (Moore et al. 2001).

Generally, bioactive ceramics have the ability to bond directly to bone. They possess both osteointegrative and osteoinductive properties and have improved mechanical properties over other bone substitutes. This most closely resembles cortical bone, refering a combination of bioactivity, strength, fracture toughness and modulus of elasticity. Bioactive ceramics have been successfully used for vertebral prosthesis in the treatment of tumours, burst fractures and as orbital implants (Thomson and Hench, 1998) and as coatines of metal implants with the aim to enhance their osteointegration (Starnd et al., 2000) The main advantage of bioactive ceramics is that it allows complete ingrowth of fibro-osseus tissue. According to Schoenaers and Holmes (1985) fifty to eighty per cent of the defect is filled within three months. At that time, the implant consisted of approximately $17 \%$ bone, $43 \%$ soft tissue and $40 \%$ residual hydroxylapatite (HAP) (Holmes and Hagler 1988). Ceramic HAP preparations are resistant to resorption in vivo, which occurs at a rate of $1-2 \%$ per year (Constantino and Friedman, 1994). Tricalciumphosphate (TCP) undergoes resorption via dissolution and 
fragmentation over a 6-18 months period. Unfortunately, the replacement of TCP by bone does not occur in an equitable way. That is, there is always less bone volume produced than the volume of TCP resorbed (Holinger and Brekke, 1996). For this reason the clinical use of TCP has been an adjunctive with other less resorbable bone graft substitutes.

Calcium hydroxylapatite (Hap) was synthesised chemically in Serbian Academy of Sciences and Arts. The obtained Hap was of high purity and crystallinity. Artificially synthesized Hap proved to be a successful substitute for natural Hap. Hap is used in medicine and stomatology for repair of bone tissue. It is known that calcium phosphate ceramic is used as a filling for periodontal defects, as a preservative augmentator for alveolar ridges and as an interpositional bone substitute in dental practice. In the mean time those materials are used for definitive root canal obturation in endodontic therapy procedure as filling materials.

This study was undertaken with aim to evaluate the biological response of bone to hydroxylapatite (Hap) and the mixture of HAP and tricalciumphosphate (TCP) used as graft materials.

\section{MATERIAL AND METHODS}

\section{Experimental animals}

Male Albino Wister rats $(n=36)$ averaging from 250 to 300 gr. were studed. Ethical committee of Faculty of Stomatology Belgrade University approved the study design. Mature Wister rats were cared for according to the European (OEDC) requirements for "Good Laboratory Practice".

\section{Materials used}

The following materials were used:

Hydroxylapatite-Hap (PAT 285/91) Institute for Materials, Serbian Academy of Science and Art, Hydroxylapatite sealer-Hap M type 2 (65\% Hap, 35\% TCP, $0.15 \mathrm{ml} / \mathrm{g}$ saline) and Rose wax (Galenika, Serbia).

\section{Experimental procedure}

The animals were anaesthetized with Nembutal $(0.1 \mathrm{ml} / \mathrm{kg})$ administered intraperitoneally. The femur bone was exposed and identified between femoral muscles. According to the surgical procedure the femur was fixed in situ. A round steel burr (No 1) was used to create the bone cavities (with continuous saline irrigation) $3 \mathrm{~mm}$ diameter length and $2 \mathrm{~mm}$ depth. In the artificially prepared cavities the investigated materials were implanted. After implantation, the muscles were allowed to return to their natural arrangement and the skin was sutured. The animals were signed on the left or right ear according to the implanted materials, without antibiotics support and returned to the cages. We anticipated that animals would not suffer during and after the experiment.

The animals were sacrificed by standardized pharmacological euthanasia by giving a lethal dose of Nembutal 4, 12 and 24 weeks after surgery. Femur 
bones with the implanted material and surrounding tissues were removed and processed for histological analysis on light microscope.

\section{Histological procedure}

The material for histological analysis was fixed in $10 \%$ buffered formalin, decalcified in $10 \%$ formic acid $(\mathrm{pH}=5)$ and embedded in paraffin. Serial sections $8 \mu \mathrm{m}$ thick were cut parallel to the long axis of the femural bone. The sections were stained with haematoxylin and eosin and were analysed microscopically (LM Leica). The quality of the implants was analysed in the light of the biological response of tissues. Histological analysis was preformed according to the following criteria:

1. Integration of the grafted material with the original bone and the possibility to establish a solid interface with complete fusion between the material's surface and the bone tissue with no fibrous tissue interface.

2. Appearance of new ossification centres in the region where the bone was surgically removed, with determination of bone formation and bone resorption parameters.

3. Inflammatory response of the surrounding tissue to a foreign material, which can be considered as one of the major parameters for the biocompatibility test in vivo.

4. Angiogenic response of the tissues, which is one of the major factors in wound healing and tissue remodelling.

\section{RESULTS}

Histological analysis of healing responses in bone defects treated with HAP eight weeks and six months after implantation

Eight weeks after surgery the results of histological analysis revealed that in all examined samples the graft material appeared as a spherical calcified structure in various forms and sizes (Fig.1). Large amounts of mineralised new bone were seen surrounding graft particles. The bone was mainly of the temporary, immature type, with an irregular array of collagen fibers, lower mineral content and a higher proportion of osteocytes in lacunae indicating the vitality of bone. Osteoid was seen in close proximity to newly formed bone, confirming that active osteogenesis was still in process. Lamellar bone was occasionally seen next to immature bone thereby demonstrating the beginning of mature bone formation. The active bone marrow was present in spaces between bone trabeculae in almost all analysed samples. The interface between graft material and bone was not intimate in any of the analysed samples. In none of the samples the particles of the graft material were covered with osteoid. The graft material was surrounded by highly cellular loose connective tissue. The cells of inflammatory infiltrate were not present in any of the analysed samples indicating biocompatibility of the graft material. The demarcation line between surgically created defects and surrounding bone was clearly seen in all samples. In most of the analysed samples connective tissue did not interface between newly formed 
bone and surrounding bone at the borders of the defects. In a few samples $(n=12)$ the borders of the defect were partly covered by connective tissue, which could not cause failure of osteogenesis. Ossification of the defect occoured in both ways, intramembranous and endochondral. Therefore, areas of hyaline cartilage were seen in the bone defect (Fig. 2).

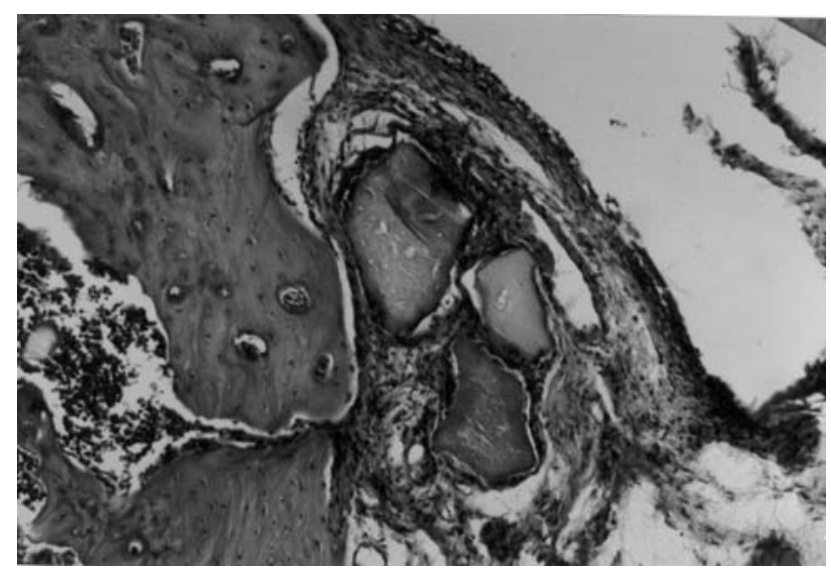

Figure 1. H.E. 100x. Microphotograph of the bone defect treated with Hap as graft material eight weeks after the surgery. Bone defect was partially filled with newly formed bone. Large amounts of the graft material surrounded by highly cellular connective tissue were still present

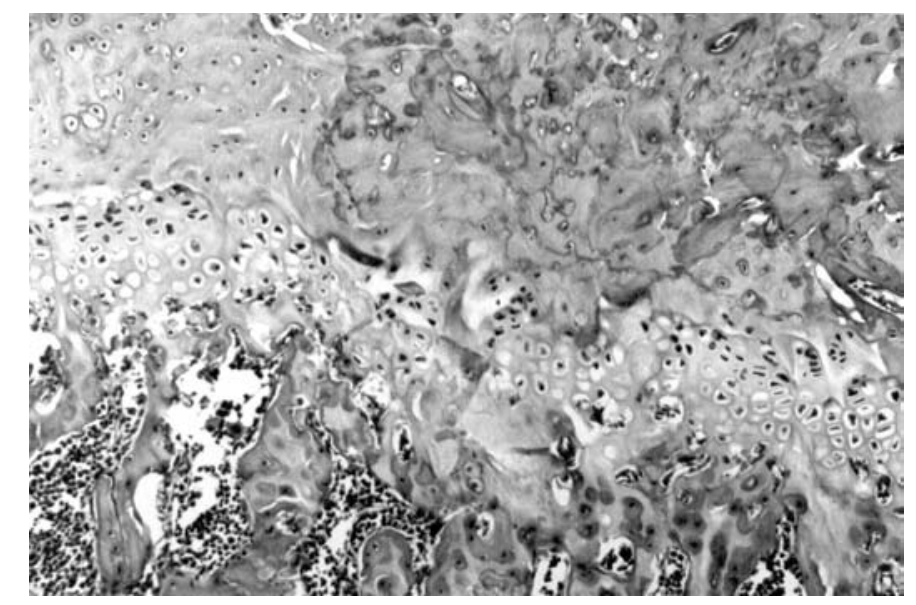

Figure 2. H.E. 40x. Microphotograph of the bone defect treated with Hap as graft material eight weeks after the surgery. The area of hyaline cartilage indicate that osteogenesis was preformed in both ways: intamembraneous and endochondralis 
Six months after surgery the repair of bone tissue progressed in such a way that bone callus was completely resorbed and replaced by secondary, mature bone (Fig. 3). The original bone structure was completely restored with a hardly seen demarcation line at the border of the defects. The interface of newly formed bone and surrounding bone was intimate without interfering connective tissue. The particles of the graft material could not be seen in any of the analysed samples.

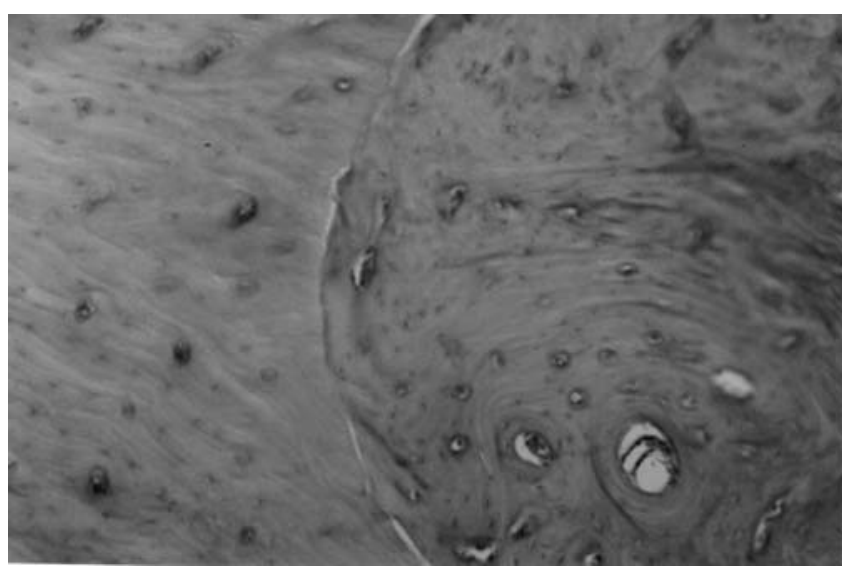

Figure 3. H.E. 400x. Microphotograph of the bone defect treated with Hap as graft material six moths after the surgery. Bone structure was completely restored. Demarcation line was hardly seen

Histological analysis of healing responses in bone defects treated with the mixture of hydroxylapatite and tricalciumphosphate (HAP and TCP) eight weeks and six months after implantation

Two months after implantation of the resorbtive graft material bone defects were filled with highly cellular, vascularized, young connective tissue. The repair of bone occurred in all samples, but the amount of newly formed bone was significantly smaller than in defects treated with HAP. The particles of the graft material were surrounded by connective tissue. Erosion sites with multinucleated cells, resembling osteoclasts could be identified at the peripherial parts of the particles in most of the sections (Figs. 4 and 5). Six months after the implantation bone repair was still not completed, with connective tissue interfacing the surrounding bone. There were no signs of inflammation in any of the examined sections, suggesting biocompatibility of the graft material. 


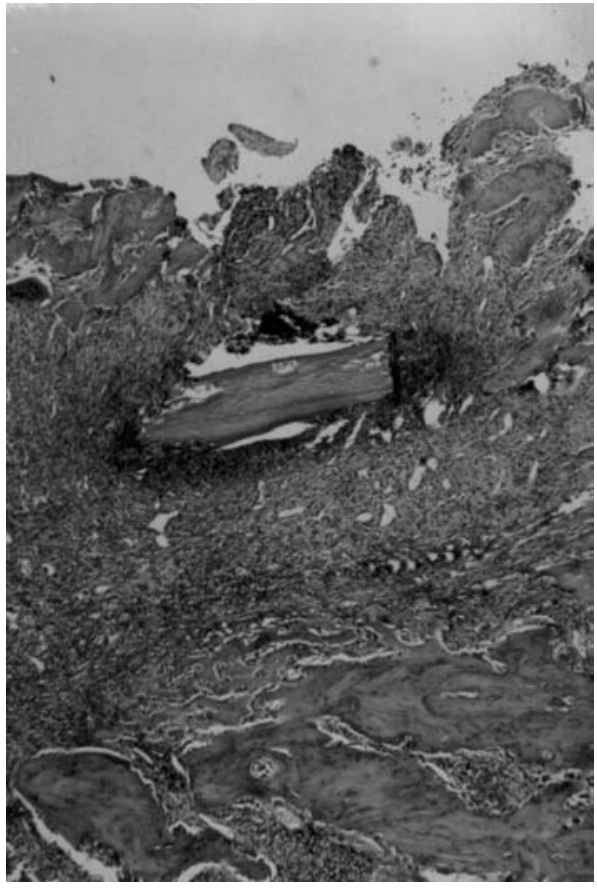

Figure 4. H.E. 40x. Microphotograph of the bone defect treated with Ceros white $^{R}$ (commercial tricalciumphosphate) as graft material six months after the surgery. Bone repair was markely delayed and newly formed bone was seen at the peripherial parts of the defects, while the central part was filled with highly vascular connective tissue and unresorbed parts of TCP particles

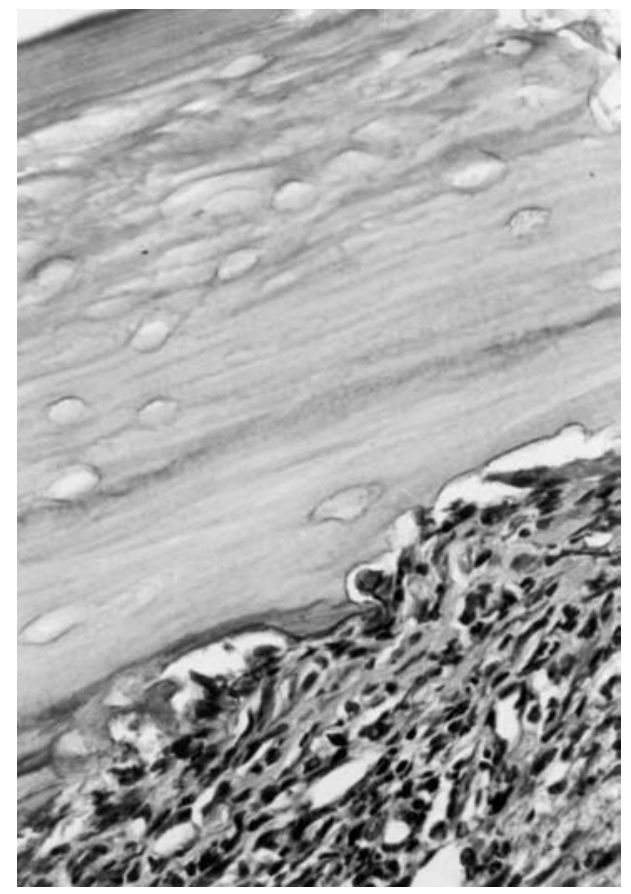

Figure 5. H.E. 400x. Microphotograph of the bone defect treated with Ceros white (commercial tricalciumphosphate) as graft material six moths after the surgery. Erosion sites of TCP particles indicated that resorption of the particle was still in process

Histological analysis of healing responses in bone defects treated with rose wax eight weeks after implantation

Two months after implantation of rose wax in the bone defect complete failure of bone repair was seen in all examined samples. The bone defects appeared as round, empty spaces, separated from surrounding bone by a connective tissue capsule, formed of dense, parallel collagene fibers (fig. 6). The connective tissue capsule was infiltrated with mononuclear cells, mainly lymphocytes and plasma cells, showing medium to severe inflammation. This could be explained as a graft rejecting reaction. Six months after surgery the tissue reaction was almost identical to the reaction observed two months after implantation. 


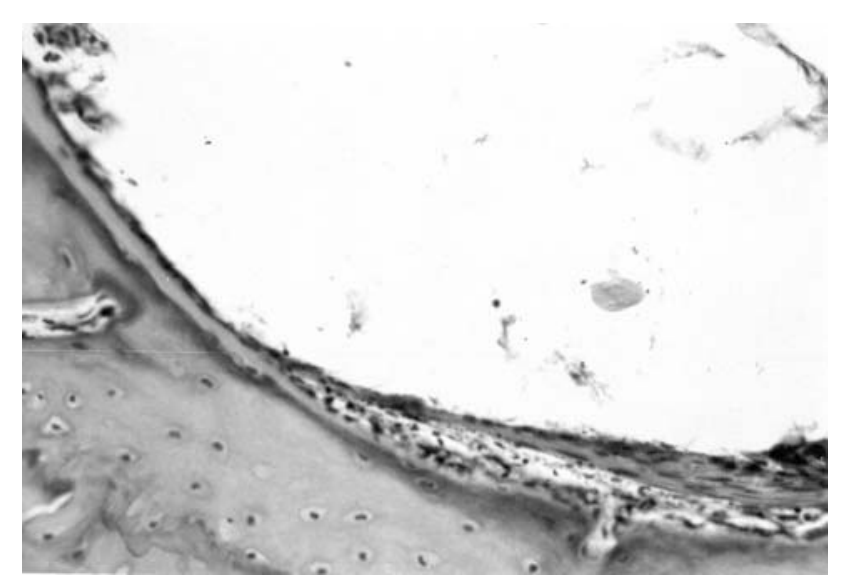

Figure 6. H.E. 400x. Microphotograph of the bone defect treated with rose wax as graft material six moths after the surgery. Bone defect was completely empty with borders covered with parallel collagenic fibers and very small area of osteoid tissue. Complete failure of bone repair indicated rejecting of rose wax as graft material

\section{DISCUSSION}

The tissue response to graft material is among other parameters, related to the characteristics of the material. Hydroxyapatite pulver and tricalciumphosphate granules enabled new bone formation in defects where bone was not present before grafting. The presence of newly formed mineralised bone covered with osteoid demonstrates that active osteogenesis is still in process, while the simultaneous presence of woven and lamellar bone with active osteoblasts and osteoclasts suggests that bone remodelling was going on at the grafted site. Osteocytes, which are completely entombed by mineralised bone, can survive implantation or die due to lack of transitional lack of vascularization (Zerbo IR, 2003). Vitality of osteocytes may be important for bone remodelling around the implant, since these cells are currently belived to be involved in bone turnover by secreting signalling molecules. These factors communicate with the bone surface, controlling the activity of surface bone cells such are osteoblasts and osteoclasts (Smit TH and Burger EH, 2002; Zhao S et al., 2002). Histological picture of bone repair in the artificially created defects suggests that immature bone was formed on the grafted site, which was later remodelled into the lamellar bone. Although bone repair occurred in defects treated with HAP and the mixture of HAP and TCP, the amount of newly formed bone was much greater and the integration with the surrounding bone at the border of the defect was much more intimate in groups treated with hydroxyapatite. Wound healing in these groups was characterized by complete regeneration. This was not the case with defects treated with the mixture HAP-TCP, in which regeneration was delayed. Expectably, rose wax caused the reaction of the rejection of the graft material, which was 
characterized by formation of connective tissue capsule, inflammation and complete absence of bone formation.

Bone formation is thought to be formed via three mechanisms: 1 . osteogenesis in which graft material contains osteoprogenitor cells, which are able to form new ossification centres; 2. osteoinduction in which graft material induces differentiation of precursor cells into bone matrix-producing cells and 3 . Osteconduction in which graft material acts as scaffolding for deposition of newly formed bone, produced by adjacent living bone cells (Groeneveld et al. 1999, Sweeney et al., 1995; Rabie et al., 1996). It is very likely that in our study bone formation occurred by osteoconduction. Some previous studies have demonstrated that octacalcium phosphate (OCT) used as a bone substitute, besides osteoconduction OCT granules can cause osteoiduction, by providing the core for nucleating multiple osteogenic sites in skull bone defects (Beck et al., 1991; Blanquaert et al., 1995; Viljanen et al., 1996, Kamakura S, 2001).

Hydroxyapatite (HAP) and tricalciumphosphate (TCP) enables bone formation by guiding osteoprogenitor cells from existing bone. Osteoprogenitor cells originating from periosteum and endosteum (Sasano $Y$ et al., 1999) differentiate into osteoblasts, which produce the bone matrix between graft particles. According to Zerbo et al. (2001), the potential of the graft material to promote bone formation depends on the porosity of the material. The size of the pores within the graft material should be large enough to allow infiltration of osteoprogenitor cells and osteoclasts. Furthermore, Zerbo et al. (2001), reported in their study in which porous tricalciumphosphate was used to obtain regeneration of human alveolar bone, the presence of bone-like matrix without any cells. This phenomenon may be explained by the diffusion of soluble procollagen molecules and other extracellular matrix proteins through pores of the graft material and their later polymerisation into fibers and osteoid-like formations. This can improve the mechanical properties of the graft material, and later have influence on bone formation and remodelling. It can be presumed that biochemical nature and similarity to bone matrix, porosity, biodegradability, mechanical strength and biological response of the tissue are crucial parameters which determine if the graft material is suitable as a bone substitute (Lin et al., 1999). Still, fundamental understanding of the mechanism by which graft materials influence the tissue response remains limited.

\section{CONCLUSIONS}

Bioactive ceramics act as fillers and have osteointegrative and conductive properties which are largely reliant on viable periosteum and bone for their success. They provide a framework for host bone formation. To ensure efficiency of that function it is likely that controlled resorption of the graft material is required.

The results of this study suggest that pure HAP and a mixture HAP-TPC could enhance healing processes in bone defects. Although the bone response to graft incorporation was similar in both groups, these findings confirmed that complete regeneration of bone was obtained only in the group treated with pure 
HAP, suggesting that TPC granules have less osteoconductive properties than pure HAP.

Address for correspondence:

Associate professor Dr Elena Krsljak

Department of Physiology,

Faculty of Stomatology

Dr Subotica 1, Belgrade

Serbia\&Montenegro

E-mail: elerene@eunet.yu

\section{REFERENCES}

1. Beck LS, Deguzman L, Lee WP, 1991, TGF beta 1 induces bone closure of skull defects, J Bone Miner Res, 6, 1257-65.

2. Blanquaert F, Saffar JL, Colombier ML, 1995, Heparan like molecules induce the repair of skull defects, J Bone Miner Res, 17, 499-506.

3. Constantino $P D$, Friedman $C D, 1994$, Synthetic bone graft substitutes. Otolaryngol, Clin North Am, 27, 1037-73.

4. Groeneveld EHJ, Van den Berg JPA, Holzman P, Bruggenkate T, Tuinzing SDB, Burger EH, 1999, Mineralization process in demineralised bone matrix grafts in human maxillary sinus floor elevations, J Biomed Mat Res, Applied Biomaterials, 48, 393-402.

5. Holinger JO, Brekke J, 1996, Role of bone substitutes, Clin Orthoped, 324, 55-65.

6. Holmes RE, Hagler HK, 1988, Porous hydroxylapatite as a bone graft substitute in cranial reconstruction. A histometric study, Plast. Reconstr. Surg, 81, 662-71.

7. Kamakura S, Sasano Y, Homma H, Suzuki O, Kagayama M, Motegil K, 2001, Implantation of octacalcium phosphate nucleates isolated bone formation in rat skull defects, Oral Diseases 7 (4), 259-65.

8. Lin KY, Barlett SP, Yaremchuk MJ, Fallon M, Grossman RF, Whitaker LA, 1999, The merit of sintered PDLLA/TCP composites in menagement of bone fracture internal fixation, Artefitial Organs, 23, 186-94.

9. Moore WR, Graves SE, Bain GI, 2001, Synthetic bone graft substitutes, ANZ J. Surg, 71(6), 354-61.

10. Rabie ABM, Deng YM, Samman N, 1996, The effect of demineralized bone matrix on the healing of intramembraneous bone grafts in rabbit skull defects, J Dent Res, 75,1045-51.

11. Sasano Y, Kamakura S, Homma H, 1999, Implanted octacalcium phosphate (OCP) stimulates osteogenesis by osteoblastic cells and/or commited osteoprogenitors in rat, Anat Rec, 256, 16.

12. Schoenaers $J H$, Holmes RE, 1985, Healing in interconnected porous hydroxylapatite blocks: Long term histology and histomorphometry, Trans Soc Biomater, 8, 110-21.

13. Smit $T H$, Burger $E H, 2002$, A case for strain-induced fluid-flow as regulation of bone-coupling and osteonal alignment, J Bone Min Res, 11, 2021-9.

14. Strnad Z, Strnad J, Povysil C, Urban K, 2000, Effect of plasma sprayed hydroxylapatite coating of the osteoconductivity of commercially pure titanium implants, Int. J. Oral Maxillofac Implants, $15,483-90$.

15. Sweeney TM, Opperman LA, Persing JA, 1995, Repair of critical size rat calvarial defects using extracellular matrix protein gels, $J$ Neurosurg, 83, 710-5.

16. Thompson ID, Hench LL, 1998, Mechanical properties of bioactive glasses, glass-ceramics and composites, Proc Inst Mech Eng, 212, 127-36.

17. Viljanen W, Gao TJ, Lindholm TC, 1996, Xenogenic moose (Alces alces) bone morphogenetic protein (MBMP) induces repair of critical size skull defects in sheep, Int J Oral Maxillofa Surg, $25,217-22$. 
18. Zerbo LR, Antonius LJ, J Bronckers, Gert L de Lange, Burger EH, Van Beek GJ, 2001, Histology of human alveolar bone regeneration with a porous tricalcium phosphate. A report of two cases. Clin Oral Implant Res, 4, 379-84.

19. Zerbo LR, Gert L, Joldersma M, Bronckers ALJ, Burger EH, 2003, Fate of monocortical bone blocks grafted in the human maxilla: a histological and histomorphometric study, Clin Oral Implant Res, 14, 759-66.

20. Zhao S, Zhang YK, Harris S, Ahuja SS, Bonewald LF, 2002, MLO-Y4 osteocyte-like cells support osteoclast formation and activation, J Bone Min Res, 17, 2068-79.

\title{
HISTOLOŠKA PROCENA ODGOVORA KOŠTANOG TKIVA NA UGRADNJU BIOAKTIVNIH KERAMIČKIH MATERIJALA KOD PACOVA
}

\author{
KRŠLJAK ELENA, DANILOVIĆ VESNA i TEODOROVIĆ NEVENKA
}

\section{SADRŽAJ}

Eksperimentalna studija sprovedena je na 35 Albino Wistar pacova kod kojih su, veštački napravljeni defekti u butnoj kosti, popunjavani bioaktivnim keramičkim materijalima i kontrolnim materijalom. Histološka procena zarastanja defekata vršena je 8 nedelja i 6 meseci nakon implantacije. Rezultati histološke analize ukazali su da je u defektima koji su tretirani biokeramičkim materijalima ostvarena koštana regeneracija, dok je u grupi koja je tretirana roze voskom, kao kontrolnim materijalom, bila prisutna reakcija odbacivanja. Na osnovu dobijenih rezultata može se zaključiti da se ispitivani biokeramički materijali mogu koristiti za popunjavanje koštanih defekata u ortopedskoj hirurgiji i stomatologiji. 